Historic, Archive Document

Do not assume content reflects current scientific knowledge, policies, or practices. 
1 


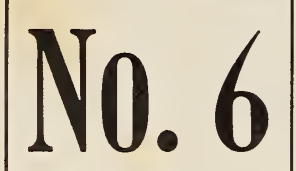
1901
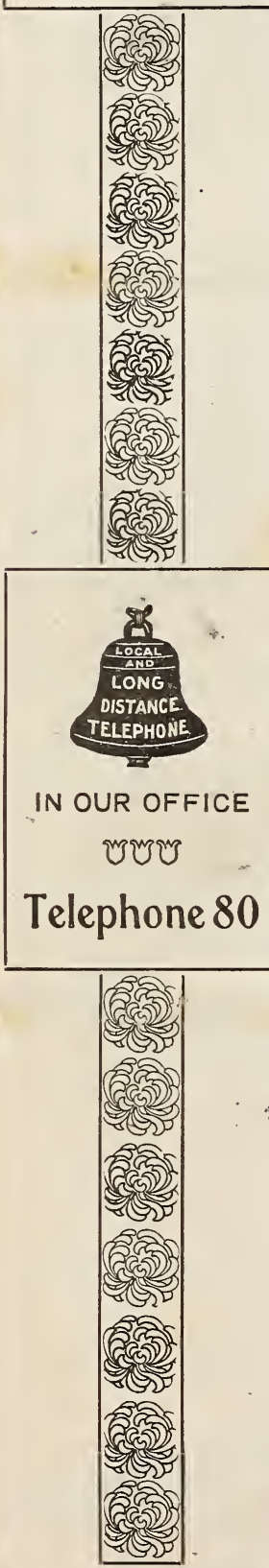

Use the Nurseryman's telegraphic code in tele. U.
ic code in tele graphing. Codes will be furnished on application.

- FOR NURSERYMEN ONLY.

$$
* * * \%
$$

\section{Special Trade List of}

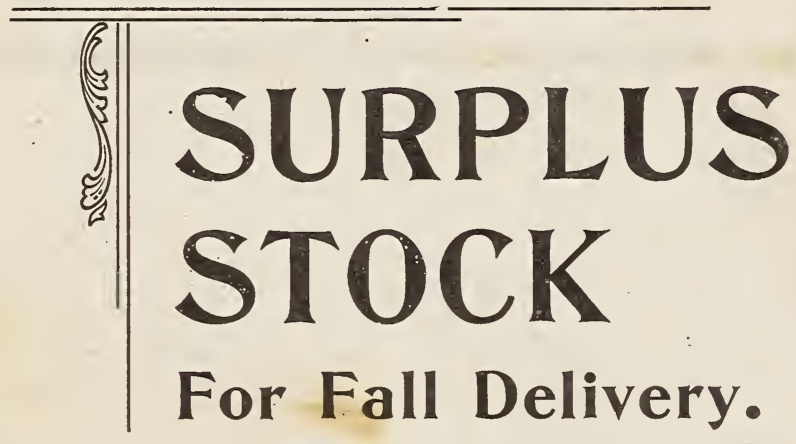

$\because$

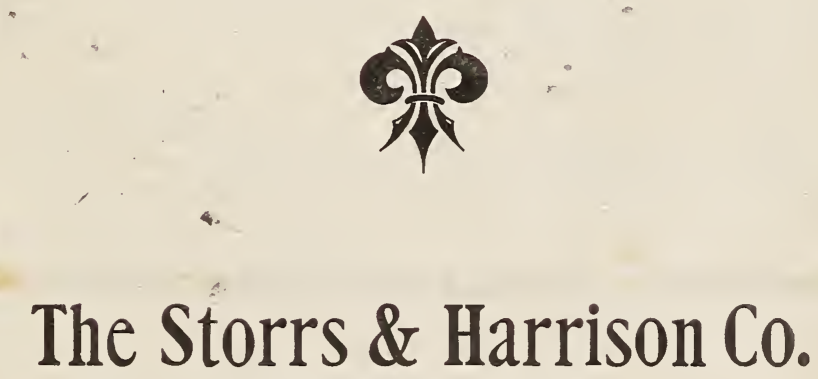

PROPRIETORS OF THE

\section{PAINESVILLE NURSERIES,}

Painesville, Lake Co., Ohio.

\section{GROUNDS AND OFFICE :}

Two Miles East of City on the North Ridge Road. 


\section{SURPLUS STOCK}

$\mathrm{O}^{\mathrm{F}}$

FFERED herein includes but a small part of the assortments we are growing. For a full list of grades and varieties, see Trade List No. 4. Everything offered is young, thrifty stock, graded to highest standard. Our two and three year blocks of Fruit Trees. Standard and Dwarf Pears, Plums, Cherries, etc., are especially fine; full list strong. heavily rooted Grape Vines and Small Fruits. In all classes of Ornamentals we have an extra fine assortment of well-grown trees, smooth and handsome. Large blocks of Carolina, Lombardy and Golden Poplars, Willows. Tea’s New Weeping Mulberry, Maples, Shrubs, Field Grown Roses, etc. Your personal inspection is invited.

Special quotations on carlots, and on lots to be cellared for spring delivery, send us your list for prices

\section{TERMS OF SALE.}

The articles in this list will be furnished to nurserymen at prices named, without regard to size of order. exeept in cases of long lists of selected varieties, when such discount will he made irom retal prices as the character of the order will justify.

We reserse the right $t 0$ select the varieties, but will give the purchaser his choice as far as connistent with our stock. In ordering, please state whether or not substituting will be permitted in case we should be short of any sort wanted.

Prices holel good only until surplus stock is sold.

Boxes and packages charged as iollows: 8 to $91 / 2$ feet long, $30 \times 30$ inches, $\$ 2.50$;

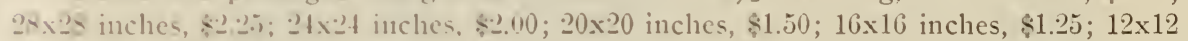
incles, ijc. Bales, in cents to $\$ 2.00$, according to size. Burlaps for wrapping the roots of Evergreens, "tc., ln cents per yard. No charge for delivering packages at Express Office or Ratilway Stations here.

Always reier to List No. ti on order.

Unknown correcpondents must send cash or satisfactory bank reference with order. Usual terms to extahlished nurserymen.

Please give plain and explicit directions as to the route and manner in which gnods are to loe forwarded, as our responsibility ends on delivering at Railway Station or Express Office.

All claims fur error, and deductions must be made within six days after receip: of stock.

Our Guarantee of Genuineness. - While we exercise the greatest diligence and care to have all our trees. etc., true to label, and hold ourselves in readiness, on proper proof, to replace all trees, etc., that may prove untrue to label, free of charge, or refund the amount paicl, it in mutually understood and agreed between the purchaser and ourselves that our guarantee of genuineness shall in no case make us liable for any sum greater than originally received for said trees, etc., that prove untrue.

\section{CATALOGUES.}

The following catalogues will be sent to applicants free:

No. 1.-Descriptive Catalogue of Fruit and Ornamental Trees.

No. 2.-Iescriptive Catalogue of Greenhouse and Bedding Plants, Flower ani Vegetable Seeds. Trees, Shrubs. Vines. Small Fruits, etc.

No. 3. - Issued in Autumm, includes Bulbs, Winter Flowering Plants, Trees, Grape Vines. Small Fruits, etc.

No. 4. - Trade List of Fruit and Ornamental Trees, Grape Vines, Small Fruits, Shrubs, Vines. Bulls, etc.

\section{THE STORRS \& HARRISON CO.,}




\section{FRUIT DEPARTMENT.}

We carry. one of the most complete stocks in the United States. For varieties and sizes not offered here see our Trade List, No. 4.

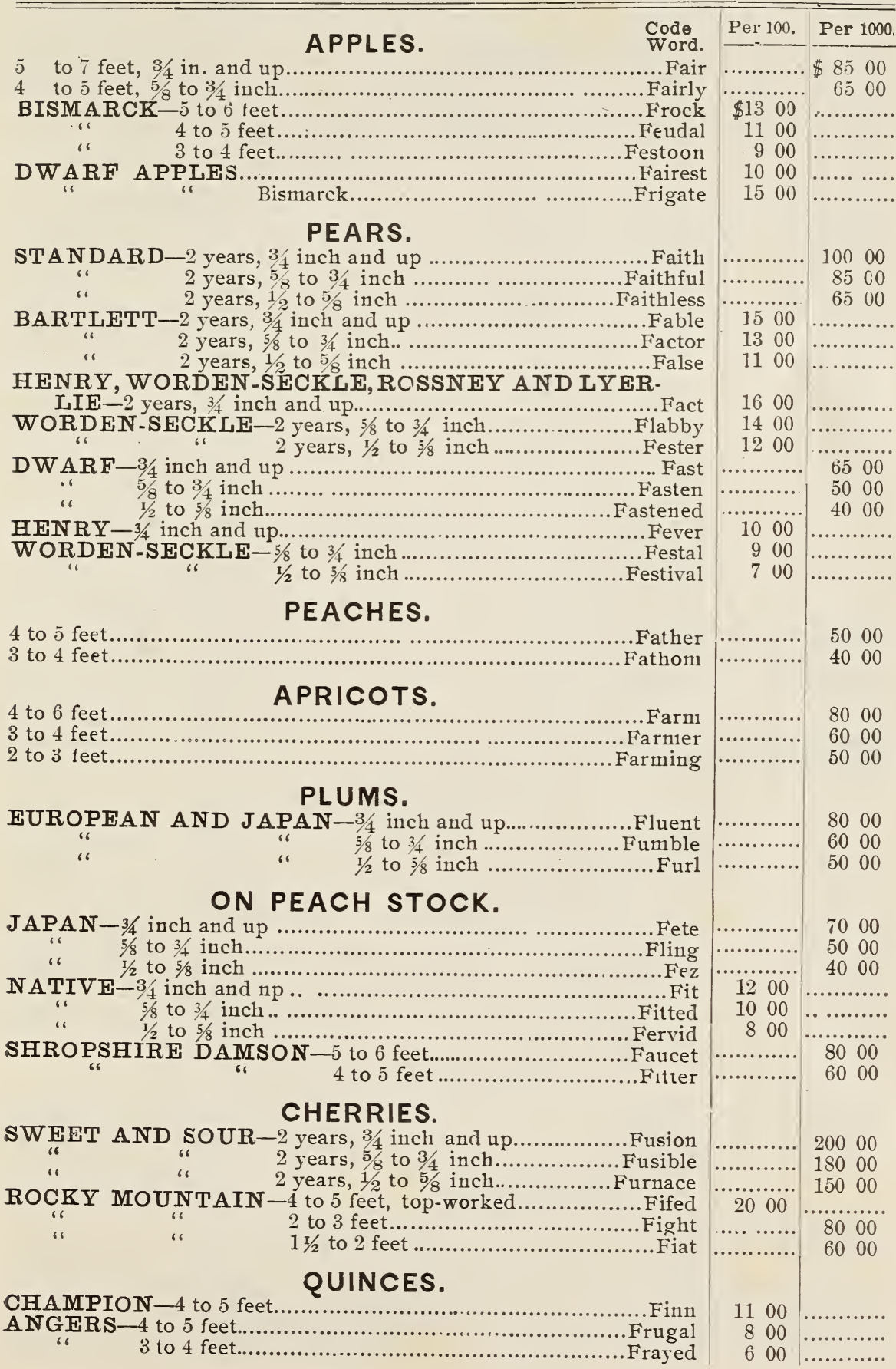


ORANGE-4 to 5 feet

$$
\text { QUINCES-CONTINUED. }
$$

MFCH's

3 to 4 feet

Code
Word. Fulcrum Fillip Fiber

\section{MULBERRIES.}

WHITE and BLACK ENGLISH-6 to 8 feet 4 to 6 feet 3 to 4 feet. Filly Flutter NEW AMERICAN AND DOWNING-4 to $\bar{j}$ feet...... Fisling 3 to 4 feet ........ Finish

\section{NUTS.}

ALMONDS- Hard Shell, 3 to 4 feet Hard Shell, 4 to 5 feet BUTTERNUTS-11,3 to 2 feet.........

$$
2 \text { to } 3 \text { feet. }
$$

Gaiting ...Gar CHESTNUT-American, 6 to 8 feet

5 to 6 feet

4 to 5 feet

3 to 4 feet

2 to 3 feet

$1 \%$ to 2 feet

8 to $1: 2$ incli

6 to $\mathrm{s}$ inch

Spanislı, 4 to 5 feet

3 to 4 reet...

$1 / 2$ to 2 feet

Ey. Reliance and Parry

Paragon, 4 to $t$ feet.

Ridgely, 3 to 4 feet

$$
1 \text { to } t \text { i feet }
$$

FILBERTS-Finglish, $11 / 2$ to 2 feet

$$
2 \text { to } 3 \text { feet }
$$

HICKORY-Shell-bark, 3 to $\&$ feet

$$
2 \text { to } 3 \text { feet... }
$$

$$
11.2 \text { to } 2 \text { feet }
$$

PECANS-12 to 18 inclies.

W ALNUTS-Japan, Sieboli, 1 i. to 2 feet.

$$
2 \text { to } 3 \text { feet }
$$

Gauge

...Gab

Gaiter .Gag

Gage

. Gain Gale

Gainer

...aily

Gentile

Gannut Garb

Gliost

Gailey Casp

Cap

Gala

...Gaul

Gaback

Galoon

. Gawk Gay Gaze ..Gin Garland Iax Cordiformis, 1 "

2 to 3 feet..

Einglish, 3 to 4 feet.

$$
2 \text { to } 3 \text { feet.. }
$$

11., to " feet.

I) warf, 112 to 2 feet

$$
2 \text { to } 3 \text { feet }
$$

Black, is to s feet....

4 to $i$ feet.

3 to 4 feet.
2 to $: 3$ feet.

11.2 to 2 fect Gill

Giggle Gild ...Gig Giziard Girder Grange Geyser Gleam Gland Gleaning ..Glean

\section{PERSIMMONS.}

AMERICAN -4 to 6 feet 3 to 4 feet Gull 2 to 3 feet Gold

11,2 to 2 feet

Grouse Goat

\section{GRAPEVINES.}

A GAW AM - 2 years ............................................... Haft BRIGHTON - 1 year ................................................... Hair

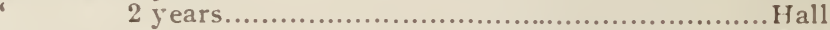
CONCORD-1 ytar Halt

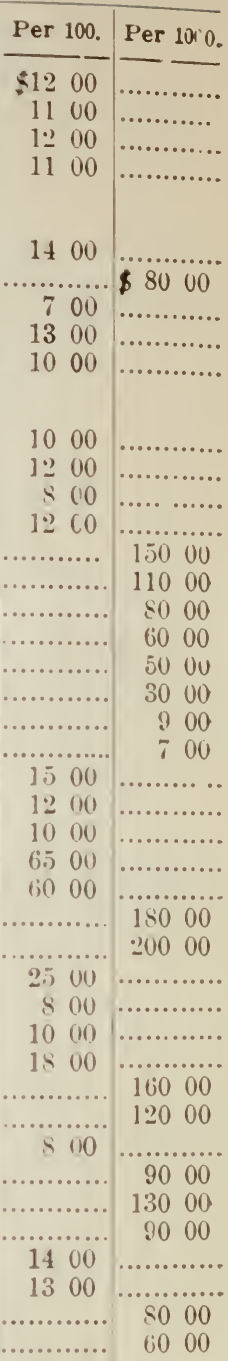

10 $\mathrm{CO}$

1200

1500

12000

8000

6000

$30 \mathrm{CO}$

12000

10000

s0 00

5000

3300

2500

4000

1500

2200

6000

8000 


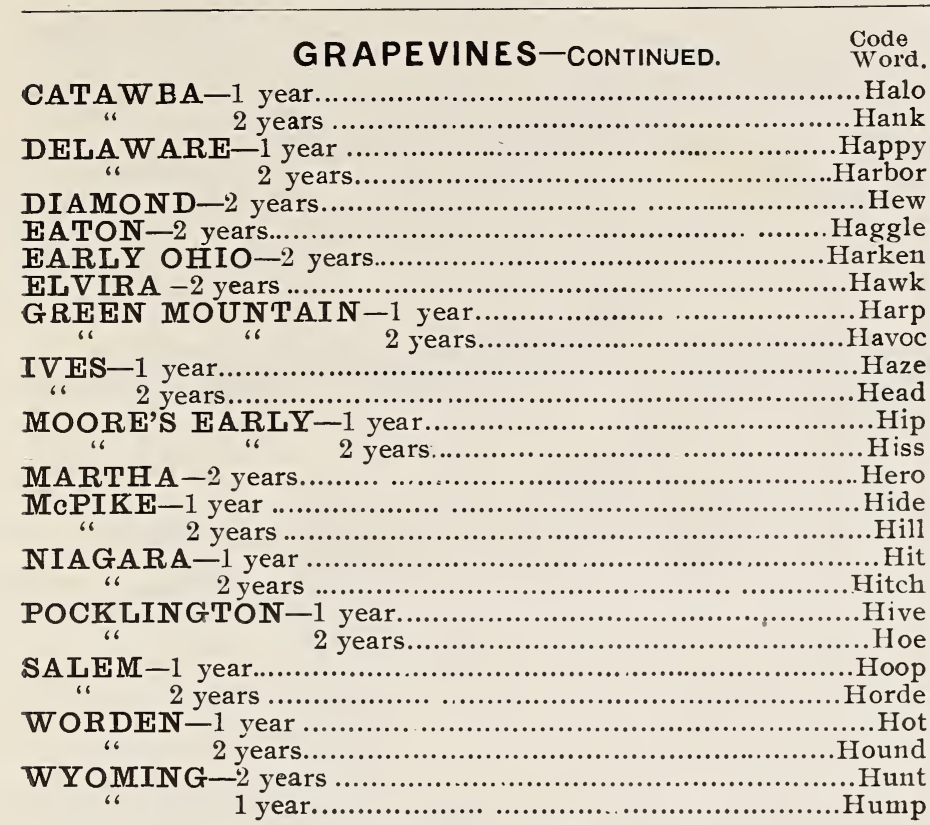

\begin{tabular}{|c|c|}
\hline Per 100. & Per 1000. \\
\hline & $\$ 2000$ \\
\hline$\cdots$ & 3000 \\
\hline & 3000 \\
\hline & 4000 \\
\hline & 3500 \\
\hline $\begin{array}{r}\$ 800 \\
750\end{array}$ & - \\
\hline & 3000 \\
\hline 1000 & .............. \\
\hline 1300 & \\
\hline n............ & 1900 \\
\hline ............ & 2700 \\
\hline ....... & 2500 \\
\hline ….......... & $40 \quad 00$ \\
\hline ........... & 3500 \\
\hline 2000 & ............... \\
\hline 2500 & \\
\hline ........ & 2400 \\
\hline ...... & 3500 \\
\hline ...... & 2500 \\
\hline ....... & 3500 \\
\hline ....... & 2500 \\
\hline ....... & 3500 \\
\hline & 2000 \\
\hline & 3000 \\
\hline ..... & 4500 \\
\hline ..... & 3000 \\
\hline
\end{tabular}

CHERRY-1 year

CURRANTS.

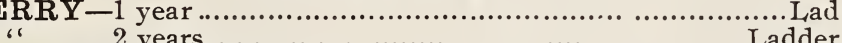

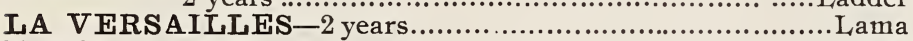

FAY'S PROLIFIC-2 years................................... Lagon

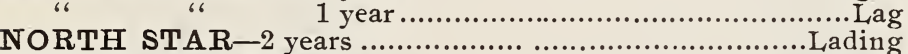

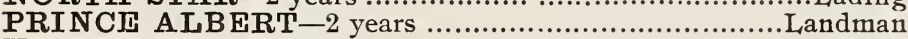

VIUTORIA -2 years .................................................. Lance

WHITE GRAPE -2 years.......................................

POMON A-2 years............................................... Langel

WILDER -2 years .................................................. Lax

GOOSEBERRIES.

INDUSTRY - 2 years.................................................. Law

COLUMB US-2 years.................................................

DOWNIN G-1 year ....................................................

“ 2 years.................................................. Lack

HOUGHTON-1 year..................................................

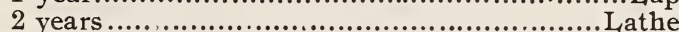

PEARL-2 years ..................................................

KEEPSAKE -2 years ................................................. Loyal

WHITE SMITH AND CROW N BOB-2 years ...................

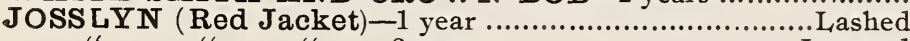
2 years ................................. Lanyard

\section{BLACKBERRIES.}

ANCIENT BRITON

ERIE

TAYLOR'S

AGA WAM

EARLY HAR VEST

KITTITINNY

Levee

Layman Leon

Logic

Legion

Levite

LUCRETIA

DEWBERRY.

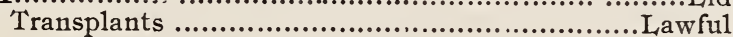

JUNEBERRIES.

IMPROVED DWARF-11/2 to 2 feet Loud

1300

1800

1800

2000

1500

1800

1800

1800

2000

3000

2500

6500

4000

1300

1800

1000

1200

2500

7500

7500

4000

4500

1000

900

1000

1000

1000

1000

800

900

7500 
RASPBERRIES. Fode
Word.
ORNGREGG, OLDER, BLACK DIAMOND and HILBORNTransplants ... HILBORN and OLDER WINEBERRY CUMBERLAND Leer KING

\begin{tabular}{|c|c|}
\hline Per 100. & Per 1000. \\
\hline & $\$ 1000$ \\
\hline & $\begin{array}{r}700 \\
10\end{array}$ \\
\hline .... & 1200 \\
\hline $\begin{array}{c}\cdots \\
\ldots \ldots\end{array}$ & 1200 \\
\hline & \\
\hline
\end{tabular}

\section{ORNAMENTAL DEPARTMENT.}

\begin{tabular}{|c|c|c|}
\hline DECIDUOUS TREES. & Per 100. & . Per 100 \\
\hline ARALIA JAPONICA -1 to 6 feet .............................. & $\$ 2500$ & \\
\hline " 6 to 8 feet.............................. Iorsel & 3000 & \\
\hline $\begin{array}{l}\text { A- } 4 \text { to } 6 \text { feet.. } \\
8 \text { to } 10 \text { feet. }\end{array}$ & 3000 & \\
\hline $\begin{array}{c}\text { " } \\
\text { ILANTHUS-S to } 10 \text { feet } . . . . . . . . .\end{array}$ & & \\
\hline $\begin{array}{r}\text { ILANTHUS- } S \text { to } 10 \text { feet } \ldots \\
10 \text { to } 12 \text { feet.... }\end{array}$ & $\begin{array}{ll}20 & 00 \\
30 & 00\end{array}$ & \\
\hline ALDER, EUROPEAN-6 to \& feet... & 1200 & \\
\hline “" 8 to 10 feet... & 1800 & \\
\hline SH, EUROPEAN-6 to $\&$ feet............... & & $\$ 10000$ \\
\hline " $\quad$ " $\quad 8$ to 10 feet... & & 2000 \\
\hline 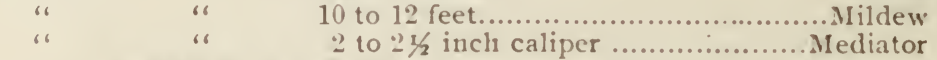 & 5000 & 1600 \\
\hline 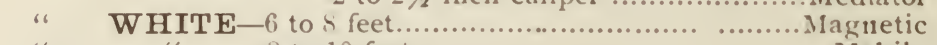 & & 13000 \\
\hline “ 8 to 10 feet...... & & \\
\hline 10 to 12 feet............................... & $2: 00$ & \\
\hline T -6 to $s$ feet. ............................. & & \\
\hline " 8 to 10 feet ................................ & & \\
\hline “ GREEN-6 to 8 feet....................................... & & \\
\hline MELANCHIER BOTRYAPIUM- & & \\
\hline ALM OF GILEAD - 8 & 0 & \\
\hline “ “ & & \\
\hline " " " " 2 to $23 / 2$ inches.......................... & & \\
\hline BIRCH, EUROPEAN WHITE- $i$ to $s$ feet ................... & & \\
\hline “ PURPLE-LEAF-3 to 4 feet $\ldots \ldots \ldots \ldots \ldots \ldots \ldots \ldots \ldots \ldots \ldots \ldots$ & & \\
\hline $\begin{array}{l}\text { “ } \quad \text { YELLOW }-4 \text { to } 6 \text { fee } \\
\text { RED } 6 \text { to } 8 \text { feet....... }\end{array}$ & & \\
\hline 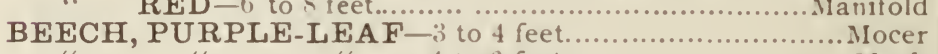 & & \\
\hline "6 6404 & & \\
\hline 6 to $\&$ feet... & & \\
\hline 8 to 10 feet....................... Ius & & \\
\hline River's Grafted, 6 to $s$ feet ...... & & \\
\hline " 6 " $" 8$ to 10 feet .... & & \\
\hline FERN-LEAVED-2 to 3 feet ....................... & 40 & \\
\hline (................. & & \\
\hline $\begin{array}{r}\text { ROPEAN-3 to } 4 \mathrm{f} \\
4 \text { to } 8 \mathrm{fe}\end{array}$ & & \\
\hline ..................... & 00 & \\
\hline "TRI-COLC & & \\
\hline IRD-CHERRY- 4 to 6 & & \\
\hline ORNUS MASCULA- & & \\
\hline APAN FLOWERING -6 to 8 feet, top........... & & \\
\hline ............. & & \\
\hline (n................ & & \\
\hline A B APPLE-Bechtels Doul & 2000 & \\
\hline & & $\begin{array}{l}10000 \\
12000\end{array}$ \\
\hline u & & $\begin{array}{l}12000 \\
17000\end{array}$ \\
\hline inch.......... $\mathrm{Nan}$ & 3500 & \\
\hline
\end{tabular}


DECIDUOUS TREES.-Continued

CATALPA-Teas, Japan and Speciosa, $2 \frac{1}{2}$ to 3 inch BUNGEII- 8 to 10 feet, top worked 6 to 8 feet, top worked

CYPRESS-DECIDUOUS -4 to 5 feet

6 to 8 feet

\section{"6}

EUONYMOUS-European (Strawberry Tree), 4 to 5 feet.....Nahant ELM-American White and Scotch, 6 to 8 feet.....
8 to 10 feet. Nacoma

$$
\text { " } 10 \text { to } 12 \text { feet. }
$$

$13 / 4$ to $2 \mathrm{inch}$.

2 to $2 \frac{1}{2}$ inch.

Red or Slippery, 6 to 8 feet...

$$
8 \text { to } 10 \text { feet.... }
$$

$13 / 4$ to 2 inch

2 to $2 \frac{1}{2}$ inch

Huntington, 6 to 8 feet

$$
8 \text { to } 10 \text { feet. }
$$

10 to 12 feet

Purple Leaved, 6 to 8 feet. 8 to 10 feet

“6

10 to 12 feet.

Doveii, 6 to 8 feet.

8 to 10 feet.

English, 8 to 10 feet.

$$
6 \text { to } 8 \text { feet. }
$$

HORSE CHESTNUT- 4 to 5 feet.

$\begin{array}{ll}66 & 6 \\ 66 & 6 \\ 66 & 66 \\ 16 & 6\end{array}$

HACKBERRY

“"

5 to 6 feet.

6 to 8 feet.

Double White, 4 to 6 feet

Red, 4 to 5 feet 6 to 8 feet.

\section{feet.}

4 to 5 feet.

IRON WOOD-3 to 4 feet.

JUDAS TREE-3 to 4 feet.

$$
4 \text { to } 6 \text { feet. }
$$

Japan, 2 to 3 feet

KENTUCKY COFFEE TREE-6 to 8 feet.

4 to 6 feet $\ldots . . . .$.
ATA -3 to 4 feet

$$
\text { A PANICULATA-3 to } 4 \text { feet. }
$$

KOELREUTERIA PANTEN-European, 6 to 8 feet.

LINDEN-European, 8 to 10 feet.

10 to 12 feet.

2 to $21 / 2$ inch

American, 6 to 8 feet.

$$
8 \text { to } 10 \text { feet }
$$

10 to 12 feet.

2 to $2 \frac{1}{2}$ inch

Silver, 6 to 8 feet.

8 to 10 feet.

10 to 12 feet.

Gold-twig, 6 to 8 feet

$$
8 \text { to } 10 \text { feet }
$$

LABURNUM-Scotch, 4 to 6 feet

$$
3 \text { to } 4 \text { feet. }
$$

LARCH-European, 2 to 3 feet.

$$
3 \text { to } 4 \text { feet }
$$

$$
4 \text { to } 6 \text { feet }
$$

MAPLE-Rock or Sugar, 6 to 8 feet

$$
\text { " } 8 \text { to } 10 \text { feet... }
$$

10 to 12 feet

$$
\text { " } \text { " } \text { " } 10 \text { to }
$$

“ 2 to $21 / 2$ inch

Norway, $b^{2}$ to 8 feet

8 to 10 feet.
Code

Word.

Naillon

Nargold Name Neighbor Navy ...Nane Namsos Nadua Nicario

Niceton ...Niles Nantic Noah ... Nora Nuncio Nunnery Nimble Nuptial Nickel Narrow Noniad .Nailed ..Nail Pablo Paste Pacolet Parmesa ..Paces .Pamet Plummet Plumbline Pascup Prairie Parable Pluralist Padlock ....Pain Petulant ..Pagosa .Palace Pasture Pandost ..Pawnee Pacific ..Pagan ..Padua ....Pale ..Palter ..Pluto Plumage Plumose

\begin{tabular}{|c|c|}
\hline Per 100. & Per 1000. \\
\hline$\$ 4500$ & \\
\hline 3500 & \\
\hline 3000 & ............. \\
\hline 3000 & n........... \\
\hline 4000 & ............. \\
\hline 1200 & \\
\hline & $\$ 15000$ \\
\hline & $\begin{array}{l}160 \\
220 \\
220\end{array}$ \\
\hline 5000 & ................ \\
\hline 8000 & $\cdots$ \\
\hline 1500 & …..................... \\
\hline 2000 & ..................... \\
\hline 2500 & .............. \\
\hline 4000 & ............. \\
\hline 7500 & \\
\hline 2600 & 20000 \\
\hline 3500 & ……..... \\
\hline & 20000 \\
\hline & 28000 \\
\hline 3500 & .............. \\
\hline 2500 & $\ldots .$. \\
\hline 3500 & .............. \\
\hline 2800 & . $\cdots \cdots \cdots$ \\
\hline 00 & 10000 \\
\hline & 12000 \\
\hline & 17500 \\
\hline 2500 & ............. \\
\hline 3000 & ..... \\
\hline 2700 & ....... \\
\hline 1200 & ...... \\
\hline 1800 & \\
\hline 2000 & \\
\hline 2000 & \\
\hline 2500 & $\ldots \ldots \ldots$ \\
\hline 2000 & .................. \\
\hline 2200 & ..... \\
\hline 1600 & \\
\hline 1500 & $\ldots . .$. \\
\hline & 13000 \\
\hline & 25000 \\
\hline 4000 & \\
\hline .. & 16000 \\
\hline & 20000 \\
\hline & 28000 \\
\hline 4000 & (n............ \\
\hline 2000 & ............. \\
\hline 3000 & ...... \\
\hline 4000 & .... \\
\hline 2500 & .... \\
\hline 3000 & ...... \\
\hline 1500 & .............. \\
\hline 1200 & ........ \\
\hline 1000 & \\
\hline & 12000 \\
\hline 00 & ........ \\
\hline & 16000 \\
\hline 3000 & \\
\hline & 13000 \\
\hline & 17500 \\
\hline & 160....... \\
\hline & 20000 \\
\hline
\end{tabular}
Painter Palermo ...Palate Paumart Paneton Pancina Panther Panthon Pantego Pantofle ..Pantop .Paola .Notary 


\section{DECIDUOUS TREES.--Continueo.}

MAPLE-Norway, 10 to 12 feet. 2 to $21 \%$ inches.

$$
\text { " } 2 \frac{1}{2} \text { to } 3 \text { inches }
$$

Sycamore, 6 to $S$ feet.

$$
8 \text { to } 10 \text { feet }
$$

Weirs Cut Leaved, 6 to 8 feet.

$$
\text { " " } \quad \text { " } \quad 2 \text { to } 2 \frac{1}{2} \mathrm{inch}
$$

Ash-leaved, 6 to 8 feet

$$
8 \text { to } 10 \text { feet }
$$

Reitenbachi, 6 to 8 feet

Red, 6 to 8 feet

Purple-leaf Sycamore, 6 to 8 feet.

MAGNOLIA ACUMINATA-3 to 4 feet.

$$
4 \text { to } 6 \text { feet. }
$$

8 to 10 feet

\section{PURPUREA-2 to 3 feet} TRIPETELA - 3 to 4 feet

$$
4 \text { to } 5 \text { feet }
$$

MOUNTAIN ASH-European, 10 to 12 feet

$$
12 \text { to } 15 \text { feet........... }
$$

134 to 2 inch 2 to $21 / 2 \mathrm{inch}$ 6 to 8 feet 8 to 10 feet

Oak-leaf, 5 to 6 feet 6 to 8 feet

O $\mathbf{A K}$-Burr or Mo:sycup, 6 to 8 feet 4 to 6 feet Black or Yellow and Chestnut, 4 to 6 feet English, 4 to 6 feet

$$
6 \text { to } 8 \text { feet }
$$
6 to 8 feet 8 to 10 feet 10 to 12 feet

Pyramidal, 6 to 8 feet

Pin, 4 to 6 feet

$$
6 \text { to } 8 \text { feet. }
$$$$
8 \text { to } 10 \text { feet. }
$$

Red, 4 to 6 feet

$$
\text { " } 6 \text { to } S \text { feet }
$$$$
8 \text { to } 10 \text { feet. }
$$$$
10 \text { to } 12 \text { feet }
$$

Scarlet, 4 to 6 feet

$$
6 \text { to } 8 \text { feet }
$$

White, 4 to 6 feet

$$
6 \text { to } s \text { feet. }
$$

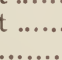

......................

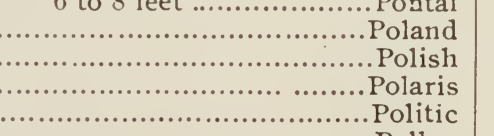
Pollex

...Pomp

Pontoon Ponert Postern ..Porcupine Polnace Pompano t........................................Porison ........................................... Popery

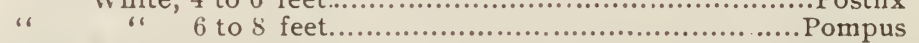
POPLAR-Aurea, 6 to 8 feet ....................................Pomona " 8 to 10 feet.....................................Pompeii 10 to 12 feet.

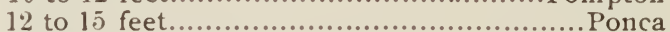
2 to $21 / 2$ inch .................................Ponesy Carolina, 6 to $\&$ feet................................. Potsdam

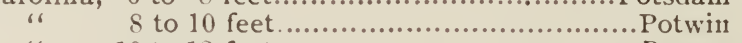
" 10 to 12 feet.................................. Pontus

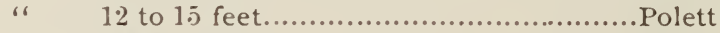
" $\quad 13 / 4$ to 2 inch ................................... Prime ، 2 to $21 / 2$ inch.................................. Prion " $21 / 2$ to 3 inch ...................................Prole

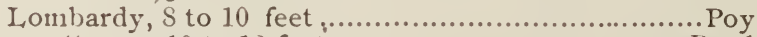

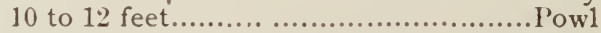

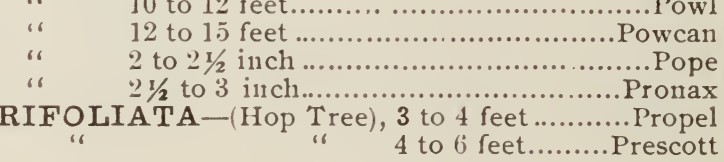

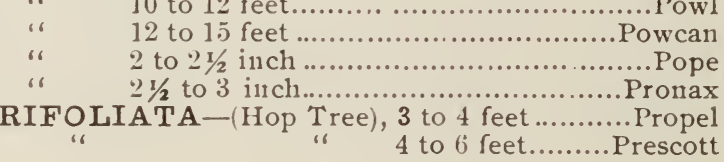

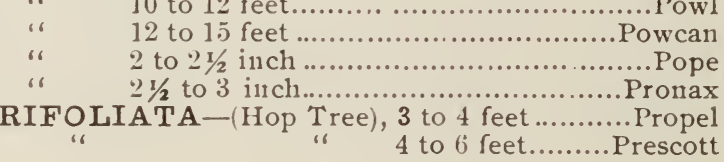

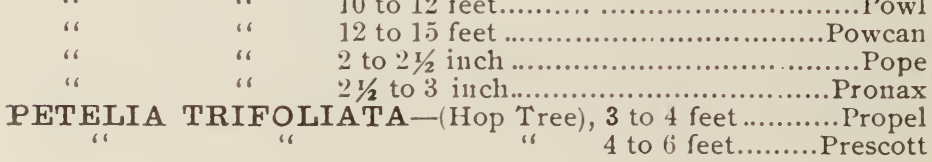

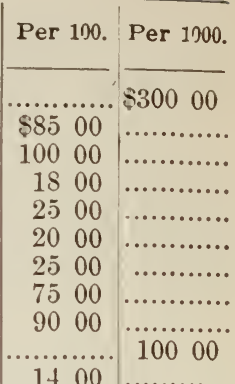

1400 4000 3000 3500 1700 2000 3500 4000 3000 4000 2000 2500 4000 6000 1400 1800 1600 2000 3500 2500 2500 3500 2500 3000 4500 6000 $50 \quad 00$ 2500 3.500 6500 3000 3500 6000 $\begin{array}{ll}75 & 00\end{array}$ 2800 4000 3000 4000

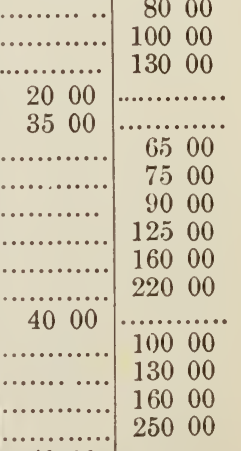

4000 700 800 


\section{DECIDUOUS TREES-CONTINUED. Pode}

PETELIA TRIFOLIATA-(Hop Tree), 6 to 8 feet.........Precious "، "، Golden-leaved, 2 to 3 feet.........Prout

ROSE ACACIA-Moss Locust, 4 to 6 feet...........................Prance

" " " " 3 to 4 feet.........................Prentiss " " $"$ Neo Mexicana, 4 to 5 feet...........................Polka " " Pendufolia Purpurea, 4 to 5 feet.............. Police RUSSIAN OLIVE-3 to 4 feet....................................Postillon SYCAMORE-European, 6 to 8 feet .............................Preserve " " 8 to 10 feet ...............................Preston " American, 6 to 8 feet...................................Putency "6 $\quad 8$ to 10 feet ............................Poverty SALISBURIA -6 to 8 feet ................................................Pliant “، $\quad 8$ to 10 feet..................................................... Prison TULIP TREE-4 to 6 feet.......................................... “ ، 6 to 8 feet................................................. THORNS-Double White, Pink and Paul's Scarlet, 3 to 4 feet ..Prigg feet .................................................... Priggish VIRGELIA LUTEA -3 to 4 feet......................................... Prink WILLOWS-Gold-bark and Laurel-leaved, 6 to 8 feet............ Prospect

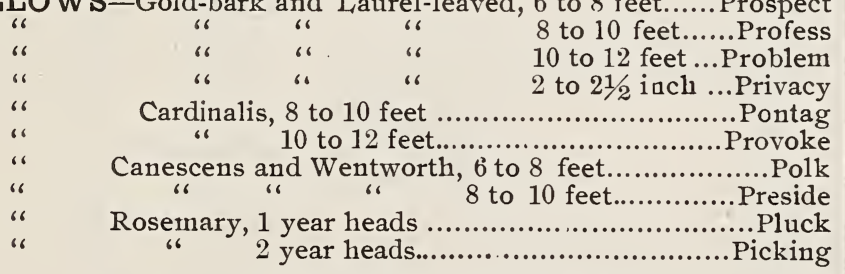

\section{WEEPING DECIDUOUS TREES.}

ASH-Gold-barked................................................... ". European .................................................................... Potter APPLE-Top-worked 4 to 6 feet..................................... Prestige BIRCH-Young's, 3 to 4 feet..................................... Pimal BEECH-Pendula, 4 to 6 feet ....................................... Poser

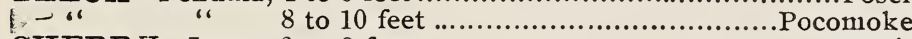
CHERR Y-Japan, 6 to 8 feet........................................Poplit ELM-Camperdown, 2 year heads..................................... Purser " Fulva Pendula, 2 year heads ..................................Putnam HONEY LOCUST-2 years........................................ Purvey

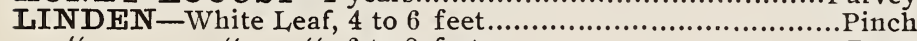
" " " 6 to 8 feet..........................................Pung " " " " 8 to 10 feet........................................ MULBERRY -Teas, New, 2 year heads.................................Pillage WILLOW-New American, 1 year heads.............................Perplex 2 year heads .............................Puritan Kilmarnock, 1 year heads...................................Pupil " 2 year heads.................................... Wisconsin, 6 to 8 feet..................................Pewter "6 8 to 10 feet...................................Petral

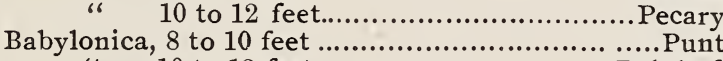

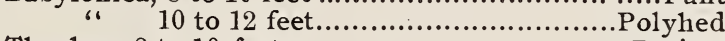
Thurlow, 8 to 10 feet...................................... Project . 10 to 12 feet....................................Prosiac

\section{DECIDUOUS SHRUBS.}

AZALEA MOLLIS-12 to 15 inches, unnamed............... Roberts al." ". 15 to 18 inches, unnamed.....................Ratio ALTHEAS-Named colors, double, 2 to 3 feet........................ Rainbow

Per $100 \mid$ Per 1000

$\$ 1200$

1300

1500

2000

$15 \mathrm{CO}$

3000

3000

1500

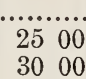

$\begin{array}{ll}30 & 00 \\ 40 & 00\end{array}$

2500

3000

4000

1500

2000

3000

1500

2000

2500

......... 10000

......... 17000

$\begin{array}{lll}35 & 00\end{array}$

1200

20 v0

1000

1200

1300

1600

4000

4000

3500

4000

5000

7500

4500

3500

3000

4000

2500

3500

4000

1000

1200

1000

1200

1000

1500

1500

2000

2000

2500

2500 3500 
DECIDUOUS SHRUBS.-Continued.

rode Word

ALMONDS-Double Flowering, White and Pink. AMORPHA FRUITICOSA - 3 to 4 feet. BARBERRY-Purple Leaved, 18 to $2 t$ inches

$$
15 \text { to } 18 \text { inches }
$$

Common, 15 to $18 \mathrm{inch}$

Thunbergii, 15 to 18 inch

COCORUS JAPONICA, fl. pl.-2 to 3 feet Variegated leaf, $11 / 2$ to 2 feet

eet

-2 to 3 feet.

CLETHRA ALNIFOLIA-2 feet

CORNUS-Siberica, 3 to 4 feet.

Paniculata, 3 to 4 feet.

Stolonifera, 3 to 4 feet

COLUTEA - Aborescens, 3 to 4 feet

CURRA NTS-Aurea and Gordonii, 2 to 3 feet

DEUTZIAS-Assorted, 3 to 4 feet..............

EXOCHORDIA GRA N DIFLORA - 3 to 4 feet................... Rutland

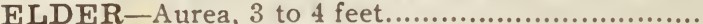

Variegated leaf, 2 to 3 feet.

Rhone

FRINGE-Purple, 3 to 4 feet.

White, 3 to 4 feet

$$
2 \text { to } 3 \text { feet }
$$

Ritcliford Riddle

Rehand

FORSYTHIA - In Variety, 3 to 4 feet.......................... Rialto HYDRA NGEA-Paniculata Grandiflora, 18 to 24 inches......Read 2 to 3 feet............Roca Tree sliape, 4 to 5

feet ...................... Raft Tree shape, 3 to 4

feet...................Rebel

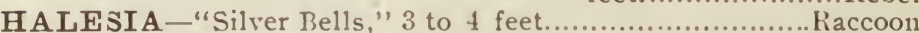
HONEYSUCKLE-Red and White Tartarian, 3 to 4 feet......Rock Grandiflora, 3 to + feet ....................... Raif Virginalis Alba, 2 to 3 feet.................... Rag

LILACS-White and Purple, 3 to 4 feet........................................ New Double, in \& varieties, 3 to 4 feet...................Reflex Rubra de Marley, "2 to 3 feet........................ Rancho Persian White and Purple, "2 to 3 feet .................. Russell

LAURUS BENZONI -2 to 3 feet............................... Recital

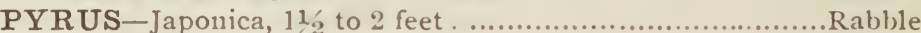

RHUS-Laciniata, 11 , to 2 feet................................. Reach

Glabra, 3 to $i$ feet ....................................... Roman

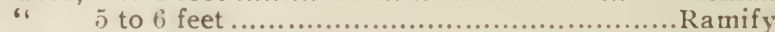

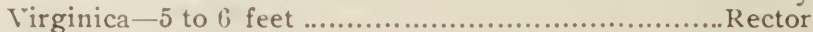

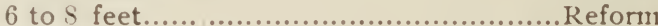

Typhena, 4 to 6 feet......................................... Rogue

3 to 4 feet....................................... Roguish

Copallina, 3 to 4 feet...................................... Ragler

RHAMNUS-Cartharticus, 3 to 4 feet ............................ Rebus

RHODOTYPUS KERROIDS-2 to 3 feet.................. Redeem

SNOWBERRY-Red and White, 2 to 3 feet ..................... Realm

SOPHORA JAPONICA - 2 to 3 feet ...................... Ranioose

SPIREAS-Fine assortment, 2 to 3 feet ...................... Rafter Bumaldi, 2 to 3 feet Van Houtte, 2 to 3 feet. Ruggerl Thunbergii, 11 \% to 2 feet.

Reindeer . Regrist

SYRINGA-(Mock Orange), in variety, 3 to 4 feet...............Rake Aurea, 15 in

TAMARIX-Iudica, Japonica, Gallica a ud African.............. Recoil

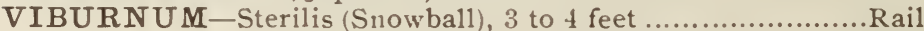
Lantana, 2 to 3 feet

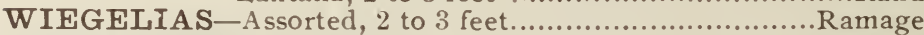

WITCH HAZEL-2 to 3 feet...................................... Rollick

Romp

XANTHOCERAS SORBIFOLIA-18 $\mathrm{inch.................} \mathrm{Relish}$

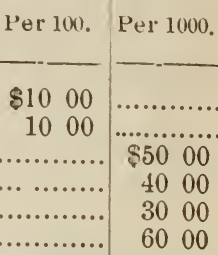

1000

1000

800

700

700

800

800

800

$\$ 00$

800

800

800

1000

1500

1500

1200

600

600

2200

So 00

1600

1200

1000

1200

1200

1500

1.) 00

12 00

1200

700

1200

1.) 00

1500

1200

1500

1500

1200

1500

800

1000

800

1500

600

7000

800

7500

1000

7000

700

1000

800

600

$\begin{array}{ll}9 & 00\end{array}$

1800

6000

10000

...........

...........

...........

..............

............

............

...........

............

........

...........

..............

8000

80 


\section{CLIMBING SHRUBS.}

A MPELOPSIS-

6"

American Ivy, strong

Veitchii, strong field.grown 2d size.

Engelmanii

AKEBIA QUINATA

BIGNONIA RADICANS

CELASTRUS SCANDENS.

CLEMATIS-Jackmani, Henryii, Ramona, etc., 2 years..

Paniculata

HONEYSUCKLES-Aurea

Halliana,

MATRIMONY VINE.

SILK VINE

WISTERIA MAGNIFICA-1 year

2 years

Sinensis, 2 years

Sinensis Alba

Multijuga, 2 years

\section{EVERGREENS.}

ARBOR VITAE-American, 12 to 15 inches

$\begin{array}{ll}66 & 66 \\ 66 & 66 \\ 66 & 66 \\ 66 & 66 \\ 66 & 66 \\ 66 & 66 \\ 66 & 66 \\ 66 & 66 \\ 66 & 66 \\ 66 & 66 \\ 66 & 66 \\ 66 & 66 \\ 66 & 66 \\ 66 & 66\end{array}$

$$
15 \text { to } 18 \text { inches }
$$

$11 / 2$ to 2 feet.

4 to 5 feet.

Eroicoides, 15 to 18 inches

18 to 24 inches.

Globosa, 15 to 18 inches.

18 to 24 inches.

Golden, 18 to 24 inches.

Hovey's Golden, $11 / 2$ to 2 feet.

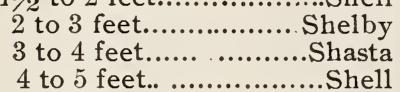

Tom Thumb, 12 to 15 inches.

15 to 18 inches..
18 to 24 inches.

CUPRESSUS-Lawsoniana, $11 / 2$ to 2 feet.

FIR-Nordmaniana, $1 \frac{1}{2}$ to 2 feet.

$$
2 \text { to } 3 \text { feet. }
$$

Balsam, 15 to 18 inches

$11 / 2$ to 2 feet.

2 to 3 feet

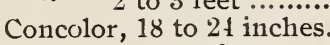

$$
\text { " } 2 \text { to } 3 \text { feet. }
$$

Violacea, 15 to 18 inches

18 to 24 inches.

Saginaw

Sumpson

...Sarp $y$

Rodent

. Rural

Rarely

Romish

Rash

Robust

...Scott

Saunders

.Sevier

Shekel

..Sable

..Shelf

Steele

Simpson

Sterile

..Stew

Satine

Sealer

Sussex

Suitor

Survey

Spokane

.Sace ade

......................... Swift

European White, 18 to 24 inches ............................ Stokes

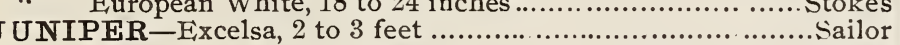

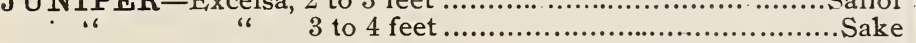

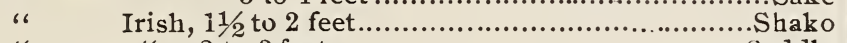

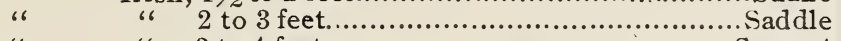

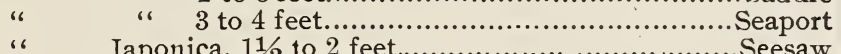

" $\quad$ Japonica, $1 \frac{1}{2}$ to 2 feet................................. Seesaw

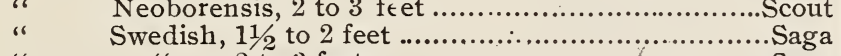

" " 2 to 3 feet .................................. Sage

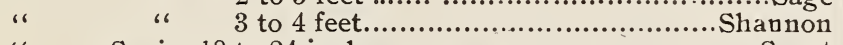

، Savin, 18 to 24 inches...................................... Scout

" " 2 to 3 feet................................... Searoom

" Suecica Nana, $11 / 2$ to 2 feet ............................. Salm

\begin{tabular}{|c|c|c|}
\hline "6 & "6 & 2 to 3 feet.................... \\
\hline “ & "6 & ............................ Scepter \\
\hline “ & Dwarf, & 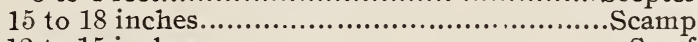 \\
\hline
\end{tabular}

"6 " 2 to 3 feet............................Salad

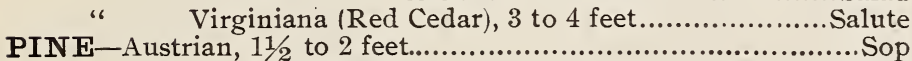

" " 12 to 15 inches..

Scarf

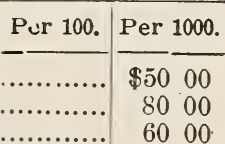

$\$ 800$

800

700

800

1600

7000

6000

800

600

5000

7000

1500

2000

1500

1200

1500

$\begin{array}{lll}10 & 00\end{array}$

1200

3) 00

1000

\begin{tabular}{l|l|l}
$\ldots \ldots \ldots \ldots$ & 100 & 00 \\
$\ldots \ldots \ldots$ & 120 & 00 \\
$\cdots \ldots \ldots \ldots$ & 120 & 00
\end{tabular}

1000

1200

1500

2000

4000

5000

1200

1500

2000

5000

6500

4000

6500

1600

1500

1800

1600

3000

4000

6500

15000

4000

3000

1200

1500

2000

1200

1.5 00

1200

1600

2000

1200

1500

2000

1600

1300

...........

.................

...........

............

............

............

………

.............

...........

............

10000

12000

............

.........

..........

..............

............

................

………

...........

.............

............. 


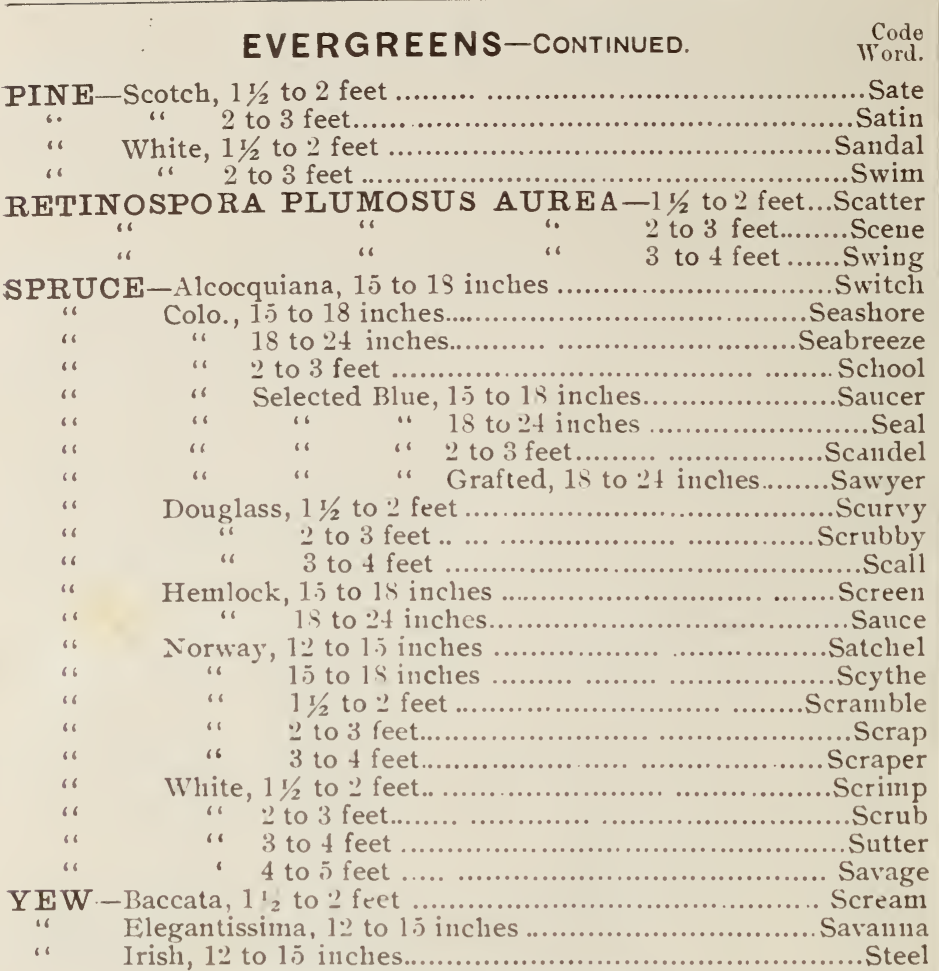

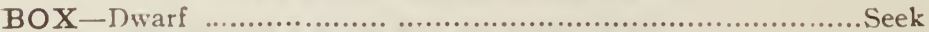
EUONYMOUS RADICANS VARIEGATA-

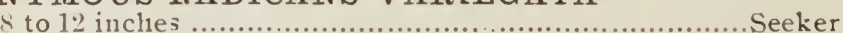

HOLLEY - American, 12 to 15 inches.......................... Sanilac

Sprinkle

MAHONIA AQUIFOLIA-12 to 15 inclies............................. Sear

\section{HEDGE PLANTS.}

BERBERRY-Conmon and Purple, 15 to 13 inclies........... Serrate Thunbergii, 10 to 12 inclies.........................Sailloft PRIVET-Ovalifolium, 15 to 13 inches ............................. Swain 12 to 15 inches ... ......................... Sermon PYRUS JAPONICA-12 to 15 inches ...........................Serpent OSAGE ORANGE - 1 year ................................... Silpin HO NEY LOCUST -2 years....................................Slump

\section{AZALEAS.}

Fine buslyy plants with good shaped heads, 10 to 12 inches in diameter ................................................... Server Fine bushy plants with good shaped heads, 12 to 14 inches in diameter Sentry

\section{TREE PAEONIES.}

\section{HERBACEOUS PAEONIES.}




\section{ROSES.}

Code

Hybrid Perpetual, largely of the following kinds: Gen. Jacqueminot, P. Neyron, A. Colomb, Baron Bonstetten, Duke of Edinburgh, Anna de Diesbach, John Hopper, Mrs. J. H. Laing, Magna Charta, M. P. Wilder, Prince C. de Rohan, Ulrich Brunner, Francois Levet, Gen. Washington, Silver Queen, Coquette des Blanches, Coquette des Alps, Mad. Gabrielle Luizet, Vick's Caprice, Marguerite Dickson, Baroness Rothschild, Fisher Holmes, Eugene Furst .................................... Shade

Earl of Dufferin, Marchioness of Londonderry, Mrs. R. G.

Sherman Crawford, Rhodocanachi and B aududclio......Supreme

Moss and Perpetual Moss, leading kinds: Blanche Moreau, Countess of Murinaise, Crested, Deuil de Paul Fontaine, Luxemberg, Salet, Glory of Mosses, Perpetual White, Princess Adelaide, Crimson Globe and Henry Martin.....S Shader Climbing-Balt. Belle, Anna Marie, Seven Sisters, Prairie Queen and Tenn. Belle.......................................... Shadow Crimson Rambler-Extra strong 2-year plants................. Shampoo White Rambler

Yellow Rambler-2-year...

Rosa IM Empress of China................................................. Sharp Yellow, Persian and Harrison's............................ Shaded Hybrid Rugosa, Mad. Geo. Bruant, Agnes Emily Carman, Blanche Double de Courber and Belle Poitevine ............ Supine Rugosa Rubra.

Dawson

Caroliniana and Lucida

Setigera

Wichuriana-Japanese Creeping.................................. Shank Wichuriana Hybrids-Universal Favorite, Pink Roamer, Manda's Triumph and South Orange Perfection ............ Sutler

Sweet Brier Bourbon-Noisette, China and Teas, 4 -inch pots................ Supper Marechal Neil-4 and 5 inch pots ............................... Shadowy Tree or Standard Shady

\section{HARDY BORDER PLANTS.}

\section{ANEMONE JAPONICA, ALBA, RUBRA AND}

WHIRLWIND

ASTILBE JAPONICA

ASCLEPIAS TUBEROSA Team Teller

ACHT AQUILEGIA, CERULEA AND CHRY SA NTHFA Tempere BOLTONIA ASTEROIDES ............................... Tricket CORFOPSIS LANCEOLATA

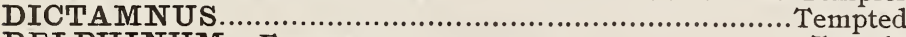
DELPHINUM - Formosum................................... Temple DORONICUM PLANTAGINEUM.............................. Triplet DICENTRA SPECTABILIS......................................... Tatt EULA LIE-Univitata, Zebrina and Variegata....................... Tenant FUNKIA ALBA .................................................. Tender

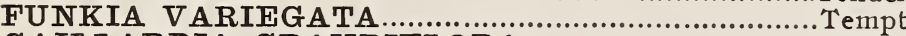
GAILLARDIA GRANDIFLORA ..........................Tendril HIBISCUS-Crimson Eye........................................ Tenor HEMEROCALLIS-Kwamso, fl. pl.- (Double Orange Lily)..Tent DUMORTIERI.............................Tepid HOLLYHOCKS-Double color, separate .......................Terrace HELIANTHUS LÆTIFLORUS AND MULTIFLORUS PLENUS

HELIANTHUS SOLEIL D'OR ......................... Terrapin IRIS-German....................................................... Kæmpferii............................................................Terrier LYCHNIS VISCARIA SPLENDENS...................... Thatch 6. CHALCEDONICA ..................................... Telico PINKS-Hardy Garden. Terror
Per 100. Per 1000

1000 7000

800

700

1000

1000

500

500

500

600

800

1000

1200

3000

5000

600

800

600

600

800

800

600

600

800

600

800

500

600

1000

800

500

600

$\begin{array}{ll}6 & 00\end{array}$

600

600

600

200

600

600

600

600

............ .......... 


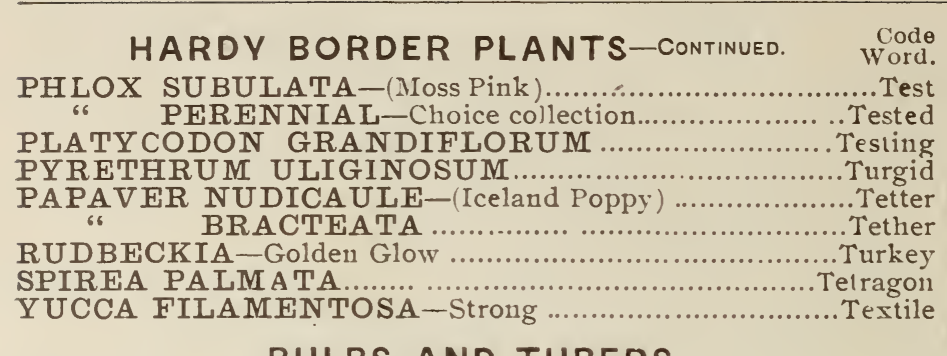

\section{BULBS AND TUBERS.}

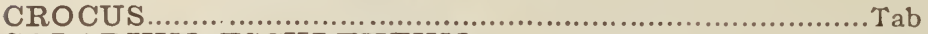

CALADIUM ESCULENTUM..................................... Table

CALLAS-Strong bulbs ....................................... Tablet

CANNAS-Dwarf French, in variety............................ Tabby

DAHLIAS-Whole roots....................................... Tabor

FREESIA-Refracta Alba............................................. Tack

GLADIOLUS - Mixed sorts, very fine.............................. Taffy

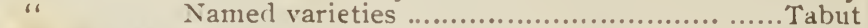

HYA CINTHUS - Candicans . ................................ Talent

HY ACINTHS-Single and Double, named varieties ............Tallow

HYACINTHS, SINGLE, NAMED COI.ORS.

Yellow, rosy white, light and dark blue, light and dark red..... Tame

White. Tamely

HYACINTHS, DOUBLE, NAMED COIORS.

Yellow, rosy white, light and dark blue. light and dark red........Tape

White........................................................... Tapis White Roman.................................................... Taper

LILIUM-Harrisii, 5 to 7 inch .................................... Tappet

A ura um (Gold Band)................................. Tardy

Batemani.............................................Tartar

Candidum11 . ............................................. Tare

Longiflorum1 ....................................................... Tariff

Speciosu1n Rubrum1 ............................................. Tart

Tigrinum, Album .................................... Tartan

NARCISSUS - Van Sion .......................................... Tarry

Double Assorted .................................Taste

Single.............................................Tattle

Chinese .........................................Tattoo

Polyanthus..................................................'Taut

TULIPS-Named varieties, double........................... Tawdry

$600 . \$ 250$

1000

600

800

$\$ 500$

800

500

600

800

$S 00$

400

500

800

.......... 800

1500

300

4000

700

400

400

400

400

250

600

$\begin{array}{ll}7 & 00\end{array}$

1000

600

500

600

700

300

200

200

2 CO

600

40 o

" " ". single..................................... Tassell

Mixed varieties, double or single...................... Ta $n$ Ty

، Parrot ..................................................... Tank 


\section{PALMS.}

We make a specialty of this class of Plants. The stock we offer is clean, healthy and well grown.

\begin{tabular}{|c|c|c|c|}
\hline & & Per 10. & Per 100. \\
\hline \multicolumn{2}{|c|}{ 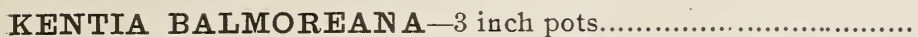 } & & \multirow{5}{*}{$\begin{array}{r}\$ 2000 \\
3500 \\
6000 \\
7500\end{array}$} \\
\hline $\log _{6 !}$ & " 4 inch pots, 12 to 15 inches high.... & & \\
\hline “ & 5 inch pots, 18 to $: 0$ inches high.... & & \\
\hline ، & 6 inch pots, 20 to 24 inches high.... & & \\
\hline ، & 6 inch pots, 24 to 26 inches high.... & 1250 & \\
\hline “" & 7 inch pots, 26 to 28 inches high.... & 1500 & \\
\hline \multicolumn{2}{|l|}{ ENTIA } & & \multirow{5}{*}{$\begin{array}{ll}20 & 00 \\
30 & 00 \\
8 & 00 \\
75 & 00 \\
. & \ldots\end{array}$} \\
\hline "6 & 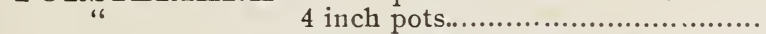 & & \\
\hline “ & 5 inch pots, 24 to 28 inches high.... & & \\
\hline “6 & 6 inch pots, 28 to 30 inches high.... & & \\
\hline “" & 7 inch pots, 30 to 36 inches high... & 1500 & \\
\hline \multicolumn{2}{|c|}{ 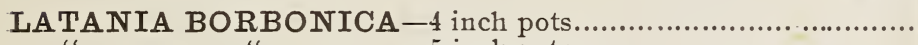 } & & \multirow{4}{*}{$\begin{array}{ll}20 & 00 \\
35 & 00 \\
75 & c 0 \\
\ldots . . . & . . .\end{array}$} \\
\hline & 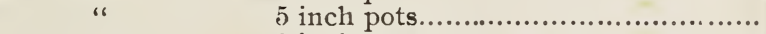 & & \\
\hline “" & 6 inch pots................................. & & \\
\hline “ & 7 inch pots..... & 1000 & \\
\hline “ & 8 in ch pots...................................... & 1000 & \\
\hline \multicolumn{2}{|c|}{$\begin{array}{r}\text { ARECA LUTESCENS }-3 \text { inch pots, } 3 \text { plants in a pot.............. } \\
4 \text { inch pots, } 3 \text { plants in a pot, } 15 \text { to } 16\end{array}$} & & 1200 \\
\hline " & 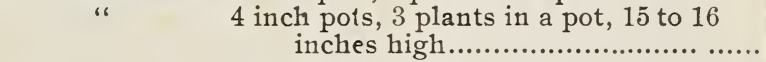 & & 2500 \\
\hline
\end{tabular}

\section{Obio Elgricultural Experiment Ftation.}

CHAS. E. THORNE, DIRECTOR.

\section{BOARD OF CONTROL.}

J. T. Robinson, President, Rockaway. R. H. WARDER, Secretary, North Bend. HoN. L. M. STRONG, Kenton. THE GOVERNOR OF THE STATE,

THE DIRECTOR OF THE STATION,

\section{DEPARTMENT}

OF

NURSERY AND ORCHARD INSPECTION.

F. M. WEBSter, Chief Inspector.

$\left.\begin{array}{l}\text { ALBERT F. BURGESS, } \\ \text { LOWELL ROUDEBUSH }\end{array}\right\}$ Assistants.

\section{Certificate of Nhursery Hngpection.}

No. 26.

Wooster, Ohio, Aug. 12, 1901.

THIS IS TO CERTIFY that the growing nursery stock and premises of The Storrs \& Harrison Co., situated at Painesville, Lake County, have been inspected by authority of an act passed by the General Assembly of the State of Ohio, April 14, 1900, and that no indications have been found of the presence of San Jose scale, Black knot, Peach yellows, or other danger= ously injurious insects or plant diseases on such stock or premises.

This certificate is void after August I5, 1902.

F. M. WEBSTER, Chief Inspector. 


$$
\approx=
$$
3. *. 1 1 , 101
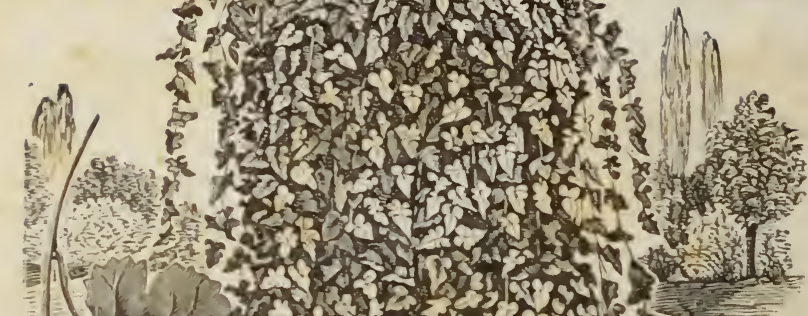

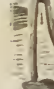
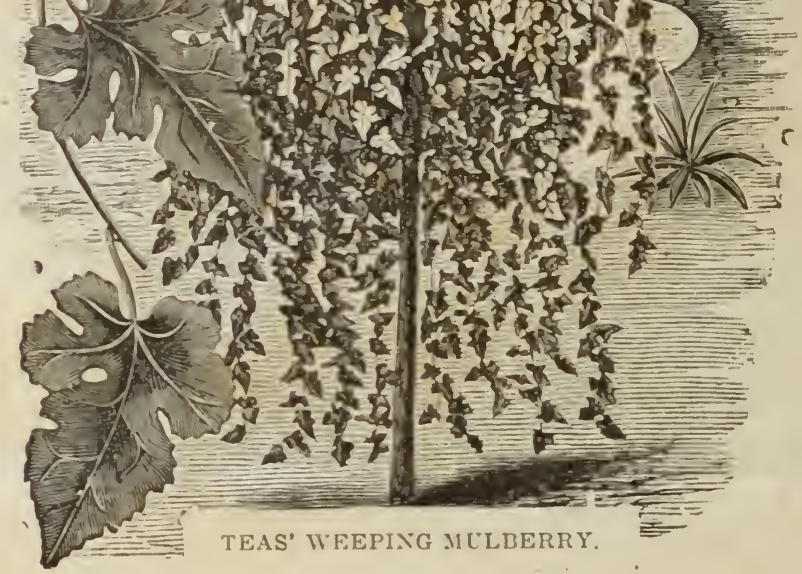